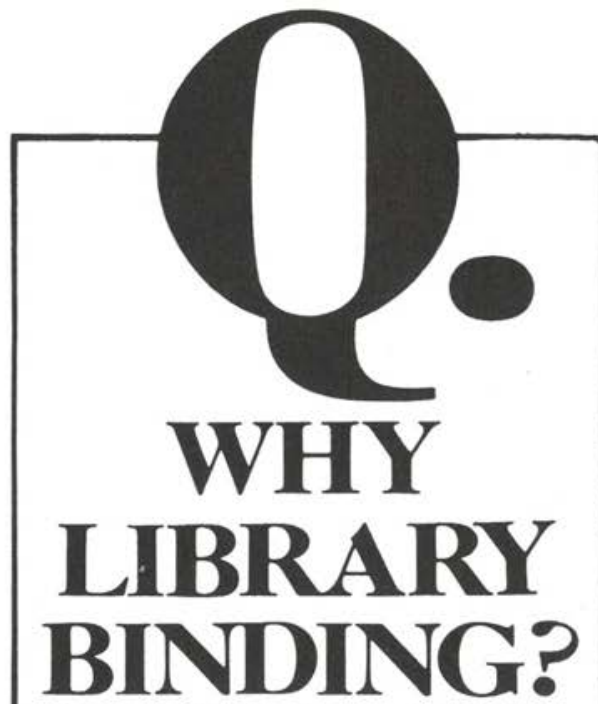

Library Binding is a special kind of binding developed primarily for libraries, and includes the initial hardcover binding of periodicals. the rebinding of used books and the pre-binding of new books all in accordance with the LBI Standard.

By specifying low cost library binding for all your binding requirements, you can save thousands of dollars in your budget (amount dependent upon size of original budget) because each volume will withstand 100 or more circulations, over four times the number provided by a publisher's library edition. This new-found money can then be used to purchase new titles, thereby increasing the size of your collection without substantially increasing the budget.

Write today for our free brochures and the name of your nearest Certified Library Binder.

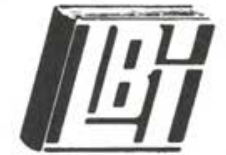

Library'Binding Institute 160 State Street, Boston, Mass. 02109
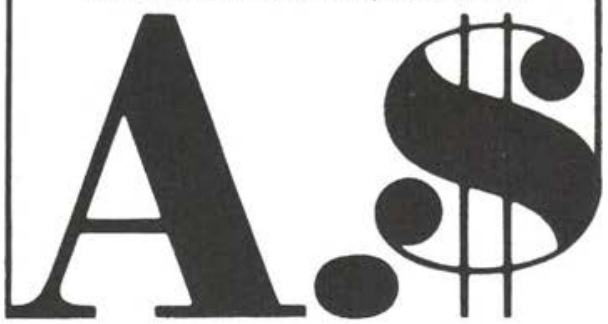

critique approach of previous building institutes with a laboratory/workshop environment

University of Rochester Library presentationBen C. Bowman, University of Rochester Library, New York; Louis E. Martin, Association of Research Libraries, Washington, DC

University of Illinois Library, Chicago Circle presentation-William B. Ernst, Jr., University of Illinois Library, Chicago Circle Campus a

\section{CAREER INFORMATION}

The job market for librarians has changed considerably. Does your library career file reflect this change? Have you replaced old materials with new up-to-date information? The Office for Recruitment of the American Library Association would like to know.

During the past year and a half the ALA Office for Recruitment has built a new selection of materials on library careers including brochures, posters, reprints, portable exhibits, and information on minority recruitment. For a complete checklist of materials and free sample copies, write to the ALA Office for Recruitment, 50 E. Huron St., Chicago, IL 60611.

-1.

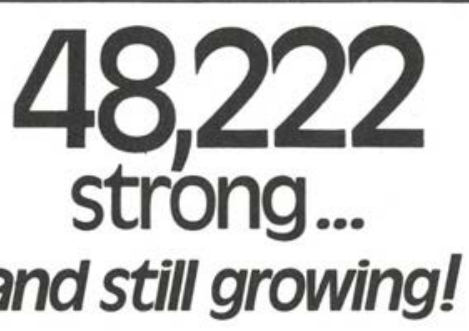

F.W. Faxon Company, the only fully automated library subscription agency in the world, has an IBM 370/145 computer currently listing 48,222 periodicals for your library.

Our 'til forbidden service the automatic annual renewal of your subscriptions - provides fast, accurate, and efficient processing of your orders and invoices.

Send for free descriptive brochure and annual librarians' guide.

Library business is our only business - since 1886.

|FWF F.W. FAXOn Co.,InC. 15 Southwest Park

Westwood, Massachusetts 02090 Tel: (800) 225-7894 (Toll Free) 